\title{
BIOGEOGRAPHY OF MAMMALS IN Rocky Mountain National PaRks
}

\author{
SUSAN M. GLENN IAN BUTLER $\bullet$ BRIAN CHAPMAN $\downarrow$ REBECCA RUDMAN \\ OKLAHOMA BIOLOGICAL SURVERY U UNIVERSITY OF OKLAHOMA \\ NORMAN
}

\section{SUMMARY OF PROGRESS TO DATE}

The first phase of the project was to determine which mammal species may have gone locally extinct from the national parks and which of these extinctions were in populations at the edge of their range. Susan Glenn met with Robert Schiller in the NPS Regional Office in Denver in July 1992. During this meeting, the validity of the park species lists was discussed. Only verified species records were being used and some groups of species had not been thoroughly inventoried in many of the parks. Species lists have not been obtained from some parks. Problems in species lists has been documented by the National Park Service (Stohlgren and Quinn 1992). Therefore, it cannot be assumed that all species that are missing from the park lists have gone locally extinct. Species habitat requirements are being analyzed to determine if the parks are likely to maintain populations of the missing species.

We acquired 3-arc second digital elevation data of the study area from Rocky Mountain Communications Inc. on CD-ROM. This data was merged for the Rocky Mountain region of the project. AVHRR satellite data has been obtained for mapping land cover. These auxiliary data layers will be used to refine the mammal distribution maps. In order to use these data, we have developed a database in dBase on habitat, and elevation range tolerance of each species. Brian Chapman, Warren Drummond and Susan Glenn visited several parks to obtain habitat information and verify species lists.

\section{PROBLEMS IN METHODOLOGY}

In the first half of the second year of the project we have identified species at the edges of their ranges and therefore were prone to extinction on National Park Service lands. We have also generated a list of species that were well within their ranges on these lands. A major difficulty has been that many species have not been adequately inventoried. Small mammals, especially shrews and bats, have not been inventoried, and these species tend to be missing from park lists. It is premature to analyze causes of these extinctions when it is not clear if these species are found in the parks. Instead of analyzing these extinctions, we have been working to determine which species have been adequately inventoried and which species require more work. The park personnel have been extremely helpful and encouraging in this process because they realize that this type of analysis was needed. Analyses of habitat requirements of species requiring inventory will help point out which species are likely to have been within the park boundaries historically.

Research into historical distributions of Rocky Mountain mammals, particularly non-games species, was difficult because the information was scattered and required extensive interpretation. This portion of the project was more time consuming and more expensive than anticipated and could easily have been a project in its own right. We particularly appreciated the assistance of Nathan Bender at Montana State University, Les Davis at the Museum of the Rockies, Paul Schullery at Yellowstone National Park, and Bob Clark of the Montana 
Historical Society.

\section{REMAINING WORK}

During the second half of the second year of funding, we will complete refining the maps of species distributions using the information regarding habitat requirements of each species. We will identify which species may have gone extinct in the park and should be inventoried. Pre-settlement species-area curves will be constructed for the region based on the GIS of pre-settlement range maps by combining species lists and areas of adjacent grid cells. Predicted species richness of native species in the park with confidence intervals of the predictions will be generated for each park as a guide to inventory completeness.

We will begin development of the modified Gap Analysis portion of the project. We will analyze species distribution patterns across the region to identify unusual species' assemblages in addition to sites with high species richness. These maps may be used for long-term planning by the National Park service and other conservation agencies in the Rocky Mountain region. Species rich grid cells and the most unusual grid cells will be identified for further investigation.

\section{- LITERATURE CITED}

Stohlgren, T.J. and J.F. Quinn. 1992. An assessment of biotic inventories in western U.S. national parks. Natural Areas Journal 12: $145-153$. 